\title{
The Administration and Management Mode of Tax Collection Based on the Concept of "Internet Plus"
}

\author{
Zhu Fang \\ Yunnan University of Finance and Economics, Kunming City, Yunnan Province, 650221, China
}

Keywords: Internet Plus, Tax collection, Administration and management mode, Reform

\begin{abstract}
Internet Plus" Initiative realized the data driving of information, and reduced the asymmetry of information, thus changed the operational state of human social economy and brought welfare to human society. Enterprises in the Internet era should establish an economic model suitable to this information pattern, otherwise they will be eliminated. "Internet Plus" is a new demand for tax system, and also is an inevitable trend of scientific progress and social development; moreover, it is an inherent demand for tax authorities to transform their functions and carry out reforms. Based on the author's study and practical experience, this paper first analyzed the problems faced by the "Internet Plus" tax collection in administration and management, and then put forward the choice and suggestions of the administration and management mode of tax collection based on the "Internet Plus" Initiative.
\end{abstract}

\section{Introduction}

In order to comply with the "Internet Plus" development trend, the State Administration of Taxation proposed to create an electronic tax bureau that integrates online and offline, so that to connects the front desk and backstage and unifies and regulates the electronic tax bureau with high efficiency on $28^{\text {th }}$, September in 2015. Moreover, they want to realize tax modernization in 2020, which is a solid step that "Internet Plus" applying in the tax system. The introduction of "Internet Plus" in the tax system will bring about a lot of changes and positive influence, especially in the aspects of internal management, tax law enforcement and tax services. As the State Administration of Taxation Director Wang Jun stressed, if tax work does not embrace the Internet, there is no future. In order to realize the modernization of taxation and construct the new ecology of electronic taxation and intelligent tax, the tax department must carry on the reform and advance the "Internet Plus Taxation" in a down-to-earth way.

\section{The Problems "Internet Plus" Administration and Management of Tax Collection Faced}

\subsection{Difficulties in Defining Tax Elements}

The identification to the taxpayer is vague. With the rapid development of network information technology and the arrival of the era of "Internet Plus", the third party network platform has been widely used in various fields. The non-national boundary of the network makes e-commerce transactions have the characteristics of non-national boundaries, diversity, uncertainty and so on, which leads to the difficulties in the identification of the taxpayer. For example, is the manager of an online store a taxpayer? Is the legal person or individual involved in the transaction the actual owner of the goods? Are they taxpayers? The appearance of the third party platform makes the participants of electronic commerce diversified, and the identification of the tax -payer is rather vague, which is different from the identification of the taxpayer under the traditional management mode.

\subsection{The Object of Taxation Nature is Difficult to Determine}

The administration and management of tax collection needs to classify the categories according to the nature of transaction object, and then to determine the specific applicable taxes. The 
development of electronic technology makes the classification of goods and services more and more difficult, and it is difficult to define tangible goods and intangible goods in electronic commerce according to the current standards. For example, purchase a software sequence number or a system authorization code through a network platform, which is not certain about the proceeds from the sale of software goods and the use of concessions, or also the proceeds of online services. If it was defined as a software subsidiary commodity, the transaction can be defined as the sale of goods such as VAT turnover tax; and if it was viewed as a right to use transactions or provide online services, it is considered a business tax. Such problems may ease after the May, 2016 when the reform ends. It can be seen that if the things were defined as different nature of the transaction, different types of taxes will be paid for the same business.

\subsection{Imperfect Administration and Management System of Tax Collection}

First, the tax registration system of electronic commerce is limited. Electronic commerce has broken rule of the tax registration in the past that engaged in production or provision of services to the tax authorities; while, it registered directly on the Internet with its own business space, and do not need to go to a specific place at a specific time for registration. Moreover, you can use the free network of mass media for the promotion of products, and engaged in various online activities the transmission of data. The Industrial and Commercial Administration Department is unable to accurately grasp the identity of the operator and the scope of business operation. As a result, business registration and tax registration are unable to track and follow up on Internet electronic commerce. Second, the accounting book voucher system of electronic commerce has limitations. According to the traditional process of collection and management, every month, quarter, and end of the year, the tax authorities check the specific books of accounts of the enterprise by looking through the tax registration and some tax payment orders related to the enterprise so that to determine whether the tax payment is reasonable and lawful. Electronic commerce has omitted many intermediate links and unified in the computer data system, and the system data can be modified at any time. Tax authorities cannot check the process and replace the voucher of process, which not only increases collection and management costs of the tax department at the same time, but also reflects the shortcomings of the traditional accounting management system. Third, the tax declaration system of electronic commerce is limited. In the current major tax declaration ways, data message declaration is more suitable for electronic commerce than door-to-door declaration and mail declaration. However, the existing laws and regulations do not explicitly stipulate e-commerce, network services and remote monitoring accounting. The legal benefits of network information data are not yet standardized. Therefore, it is difficult to accurately supervise the hidden electronic commerce by using the traditional tax declaration, and the loss of tax revenue is inevitable.

\section{The Choice and Suggestion on the Administration and Management Mode of Electronic Commerce Tax Collection}

\subsection{The Choice on the Administration and Management Mode of Electronic Commerce Tax Collection}

According to the objective reality of administration and management mode of electronic commerce tax collection in a few developed countries and economic organizations in the world, and their exploration in such area, the following modes can be used for reference: First, the tax mode of electricity consumption. Under the current policy of VAT and other indirect taxes, suppliers are required to register in all consumers' countries or regions, and suppliers will pay taxes in countries where consumption occurs. Second, it is the tracking the Internet trading information mode. Through the exchange of information on the Internet, the tax authorities accurately confirm whether all activities carried out by taxpayers on the Internet are taxable, so as to lock taxable objects. But this may, to some extent, involve citizens' privacy and tax enforcement resistance. Third, track payment patterns for electronic transactions. Payment intermediaries (e.g. banks, credit card 
companies engaged in payment transactions) may be required to be responsible for tax payment, with the main reason that consumers usually pay through a number of guaranteed and widely accepted credit cards. Generally speaking, payment is handled by a bank in the country where the consumer is located. The tax authorities can ask the bank to collect receivable taxes when consumers engage in electronic commerce transactions with foreign enterprises, and then transfer the money to the tax authorities. But the problem is that only rely on their trading data, banks can not to judge whether the consumers of the transaction need to pay taxes, nor can they decide what taxes should be paid. This mode will bring great burden to banks and related financial intermediaries. Fourth, it is the tax information exchange pattern. The tax authorities at the location of the supplier can provide sales data and information for the tax authorities of another country or region, or even levy taxes on foreign taxes. This mode is idealized, and it is difficult to operate in practice. First, the supplier in many cases does not know which country its purchaser lives in; second, the system can only be effective if all developed countries join, especially in terms of the scope, quality and means of tax information exchange.

\subsection{The Suggestions on the Administration and Management Mode of Electronic Commerce Tax Collection}

At present, the mainstream view of electronic commerce tax collection management in China is: According to the principle of tax neutrality, both electronic commerce and traditional business should bear the same tax revenue; electronic commerce can be based on the existing tax system without having to start new taxes alone; combined with the characteristics of electronic commerce, the administration and management of tax collection law of China is further improved, so that to realize the administration and management of electronic commerce tax collection. First, to perfect the registration system of e-commerce taxpayers to make special tax registration for enterprises or individuals engaged in electronic commerce, can make the tax authorities master the number of households engaged in electronic commerce in their own areas, thus effectively organize the the administration and management of tax collection work. Special tax registration management is implemented for electronic commerce taxpayers, and coordination with domain name regulatory agencies can further regulate the domain name registration. Maintaining good communication between the tax authorities and the domain name management agencies requires that the tax registration materials that should be submitted and taxpayers who are required to engage in electronic commerce should also submit the domain names or web addresses used in electronic commerce activities, as well as the specific location of the servers used by the enterprises. The tax authority shall check the relevant registration materials with the data of the domain name administration agency and issue the tax registration certificate after confirming that the application is true. Through the above registration, the tax authorities can grasp the basic situation of electronic commerce taxpayers in this area as comprehensively as possible, and create conditions for the effective implementation of administration and management of the tax collection. Second, it is the establishment of a unified national CA authentication code system. At present, the third party security certification has certain authority in electronic commerce. Therefore, the use of electronization to carry out CA certification is the basis of tax administration. For example, an electronic tax declaration and other activities can constitute an integral part of effective management only when confirming the identity of the taxpayer and passing through a third party certification with an undeniable characteristic. It is possible to establish a unified CA authentication code system in the country, and use CA authentication code as a necessary element for taxpayers to set up tax registration, tax declaration, electronic bank account, access and transfer. Thirdly, we should gradually establish an electronic declaration system in the face of many matters brought by electronic commerce, and tax authorities should speed up the tax information management in order to deal with the entire electronization and informatization problems of economy and society as well as tax issues brought about by electronic commerce. In the process of tax informatization management, it is very necessary to strengthen the construction of the software and hardware facilities of the tax authorities. We should rely on the computer network to realize the 
interconnection between the tax authorities and the relevant departments to achieve information sharing, so that to gradually establish electronic registration, electronic declaration, and the website to issue tax laws and regulations. The construction of multi-level tax service system, such as policy regulation and consultation, is carried out through the network. Fourth, as a new type of invoice, the biggest characteristic for improving the application and operation of electronic invoice is the high degree of informatization. It is a means of strengthening tax collection, invoice management, preventing and controlling invoices crime, reducing the cost of acquisition and improving the efficiency of energy saving and emission reduction. According to the operating rules, the taxpayers should log in to the portal of the tax authorities and enter the prescribed electronic invoice management system and then input relevant contents such as name, unit price and amount of goods as required.

Through the system, the tax authorities can query all the information and data of the invoices issued, and in real time understand and inquire about the true business information of the taxpayers. This helps to solve the problem of false invoices and information distortion of invoices from the source, thus preventing the loss of national taxes.

\section{Acknowledgements}

Research on Tax Collection and Management Mode under the Background of "Internet Plus" (17ZDA053). Research on Tax Gap Measurem System and Tax Policy Analysis Expansion Model (71163044).

\section{References}

[1] Chen Long. Reform of Administration and Management Mode of Tax Collection in the Internet Era [J]. Tax Collection Economic Research: 01: 44-53.

[2] Wang Zhaoyuan. Analysis on the Problems and Countermeasures of Administration and Management of Electronic Commerce Tax Collection in China [J]. Small and Medium-sized Enterprise Management and Technology (Next Edition), 2017 (03): 44-46.

[3] Chen Yaoyao, Ren Gaofei. Discussion on the Administration and Management of Electronic Commerce Tax Collection in the "Internet Plus" Era [J]. Financial Supervision, 2017, (01): 97-100.

[4] Liu Jie. Reflection on Tax Legislation under the Background of Internet Financial Innovation Mode [J]. Journal of Shanxi Radio and TV University, 2016, (04):46-49.

[5] Liu Meng, Ye Chengang. Research on Administration and Management of Tax Collection of Third Party Payment on Internet [J]. Management Modernization, 2016, (05): 26-28.

[6] Chen Yufei, Liu Jiaoyang, Tang Si. An Analysis of the Tax Problems in the O2O Mode [J]. Market Weekly (Theoretical Study: 2016: 54-56 50. 